\title{
DUCHENNE MUSCULAR DYSTROPHY IN A FEMALE WITH 45,X/46,XX CHROMOSOME CONSTITUTION
}

\author{
Motoki Sano, ${ }^{1}$ Fumiko SaIto, ${ }^{2}$ Kohtaro Yamamoto, ${ }^{2}$ \\ Akira Tonomura, ${ }^{2}$ and Hiroshi Tsukagoshi ${ }^{1}$ \\ ${ }^{1}$ Department of Neurology, Faculty of Medicine, and \\ ${ }^{2}$ Department of Cytogenetics, Medical Research Institute, \\ Tokyo Medical and Dental University, \\ Bunkyo-ku, Tokyo 113, Japan
}

\begin{abstract}
Summary The case report is that of a 23-year-old female who suffered from Duchenne muscular dystrophy (DMD). Her maternal male cousin had classic DMD and her mother showed evidence of being heterozygous for the DMD gene. By using cultured skin fibroblasts and Epstein-Barr virus transformed lymphoblastoid cell line, her karyotype was identified to be a mosaic, 45, X/46, XX. Three previously reported cases with $45, \mathrm{X} /$ 46,XX manifested both DMD and Turner's syndrome, while the present case showed no clinical features of Turner's syndrome. No clinical features of Turner's syndrome may be related to the fact that the majority of lymphocytes and fibroblasts had 46,XX. On the other hand, it is considered that the paternal $\mathrm{X}$ chromosome has been preferentially lost by postzygotic non-disjunction and that the DMD gene from the maternal $X$ chromosome is manifested in muscle cells.
\end{abstract}

\section{INTRODUCTION}

Duchenne muscular dystrophy (DMD) is an X-linked recessive disorder mostly affecting males. The manifestation of DMD is very rare in females (Walton, 1957), and might occur in the following three states: 1) homozygous state for the DMD gene, 2) preferential inactivation of the normal $X$ chromosome in heterozygous state, and 3 ) absence of the second $X$ chromosome carrying the normal gene (hemizygous state). However, homozygous state has never been reported. Many reported female cases showed balanced de novo X/autosomal translocations (Lindenbaum et al., 1979; Canki et al., 1979; Nielsen and Nielsen, 1984; Saito et al., 1985). The phenotypic expression of DMD is said to be brought about by translocation

Received May 20, 1987; Accepted July 9, 1987

Offprint request to: Akira Tonomura 
involving the DMD gene, followed by the non-random inactivation of the structually normal $\mathrm{X}$ chromosome.

The third situation refers to Turner's syndrome and DMD in a female. Five cases have been reported, and three cases of them show mosaic karyotype of $45, \mathrm{X}$ / 46,XX or 45,X/46,XX/47,XXX (Ferrier et al., 1965; Jalbert et al., 1966; Bortolini et al., 1986). The karyotype of other two cases was 45,X (Walton, 1957; Chelly et al., 1986). In each case, Turner's syndrome was observed. We report DMD in a female without Turner's syndrome, who showed a 45,X/46,XX mosaicism.

\section{CASE REPORT}

The propositus was a 23-year-old woman with presumed Duchenne muscular dystrophy. She was born after a full-term pregnancy and started to walk at 1 year 6 months. Physical and motor developments were almost normal at five years of age.

At six years of age, she had difficulty in running fast and hypertrophy at calf muscles was noticed by her mother. Although she could not run as fast as others, the patient did not feel major difficulties at school. At the age of eighteen, she had some difficulty in climbing stairs, tired more easily on exercise than before and could not lift heavy bags.

For the detailed examinations, she was admitted to the Tokyo Medical and

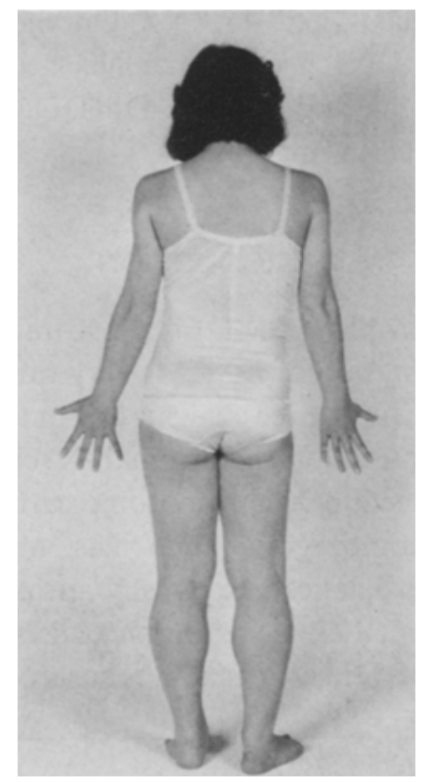

Fig. 1. The propositus at age 21 years. Note the pseudohypertrophy of the calves. 
Dental University Hospital, when she was 21 years of age. Examinations revealed the following features. Stature was $151 \mathrm{~cm}$ and weight was $55 \mathrm{~kg}$. She did not show either webbed neck or cubitus valgus. There was no evidence of cardiovascular malformation. External and internal genitalia were normal for her age. She had weakness of her extremities, a waddling gait, and increased lumbar lordosis. She showed moderately atrophied proximal muscles, enlarged calf muscles and hypoactive tendon reflexes (Fig. 1). She exhibited Gowers' sign with hands taking support on the thighs when rising up from floor.

\section{Radiographic and laboratory data}

Bone age was consistent with chronological age. Metacarpal sign was negative and carpal angle was normal in hand X-p. Gynecological examination revealed normal ovaries, uterus and upper part of vagina by echography.

The electromyographic findings were compatible with myopathic change. The serum creatine phosphokinase (CPK) level was drastically increased to 4,130 IU per liter (normal level: 25 to $170 \mathrm{IU}$ per liter). Serum aldolase was also increased to $27.3 \mathrm{U}$ per liter (normal level: 1.2 to 7.6 unit per liter).

Muscle biopsy was taken from right biceps brachii. Histological examinations showed characteristic features of Duchenne muscular dystrophy with necrotic fibers, small clusters of regenerating fibers, abnormal variation of fiber size, and increased connective tissue.

\section{Family history}

Figure 2 shows the family pedigree. Examinations have been carried out on her mother and maternal cousin. Although no muscle weakness and atrophy were detected, the CPK level of the mother was 2,012 IU per liter. The maternal cousin, a 18 years-old boy, has been confined to a wheel chair. He had clinical, electromyographic and serum enzymatic findings of Duchenne muscular dystrophy. His mother's CPK level was 1,864 IU per liter.

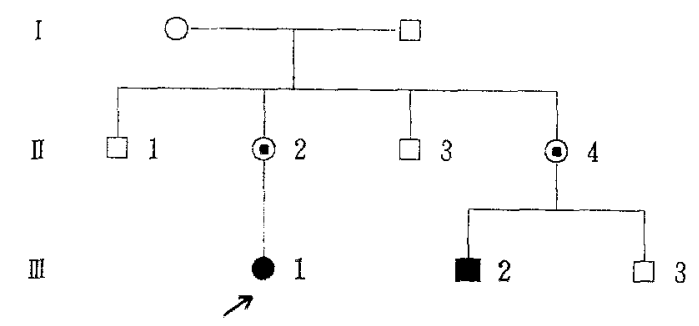

Fig. 2. Family pedigree. The heterozygous state was established by laboratory criteria in II-2 and 4. III-2 has classical Duchenne muscular dystrophy. Arrow indicates propositus (III-1). 


\section{Cytogenetic study}

The results of chromosome studies are summarized in Table 1. Chromosome analyses of PHA-stimulated lymphocytes cultured for $48 \mathrm{hr}$ were performed and demonstrated to have two major cell types: one with $45, \mathrm{XX},-\mathrm{C}$ and the other with 46,XX karyotype. G and Q-band analyses clarified the missing chromosome to be an $X$ chromosome. The number of cells with $45, X$ was only 1 out of 77 cells analyzed in lymphocyte cultures. But the presence of $45, \mathrm{X}$ cells was clearly confirmed by the examination of a lymphoblastoid cell line (LCL) transformed by Epstein-Barr virus (EBV) (Fig. 3). Twenty-nine out of 145 cells showed 45,X in EBV-transformed LCL. In fibroblast cultures from a skin biopsy, the frequency of cells with $45, \mathrm{X}$ was about $7 \%$.

Table 1. Chromosomal findings in PHA-stimulated peripheral blood lymphocytes, EBVtransformed lymphoblastoid cell line (LCL) and cultured skin fibroblasts.

\begin{tabular}{|c|c|c|c|c|}
\hline & \multirow{2}{*}{$\begin{array}{l}\text { No. of cells } \\
\text { observed }\end{array}$} & \multicolumn{2}{|c|}{ Chromosome constitution } & \multirow{2}{*}{$\%$ of } \\
\hline & & $45, X$ & $46, X X$ & \\
\hline Lymphocytes cultured with PHA & 77 & 1. & 76 & 1 \\
\hline EBV-transformed LCL & 145 & 29 & 116 & 20 \\
\hline Fibroblast cultures & 101 & 7 & 94 & 7 \\
\hline
\end{tabular}

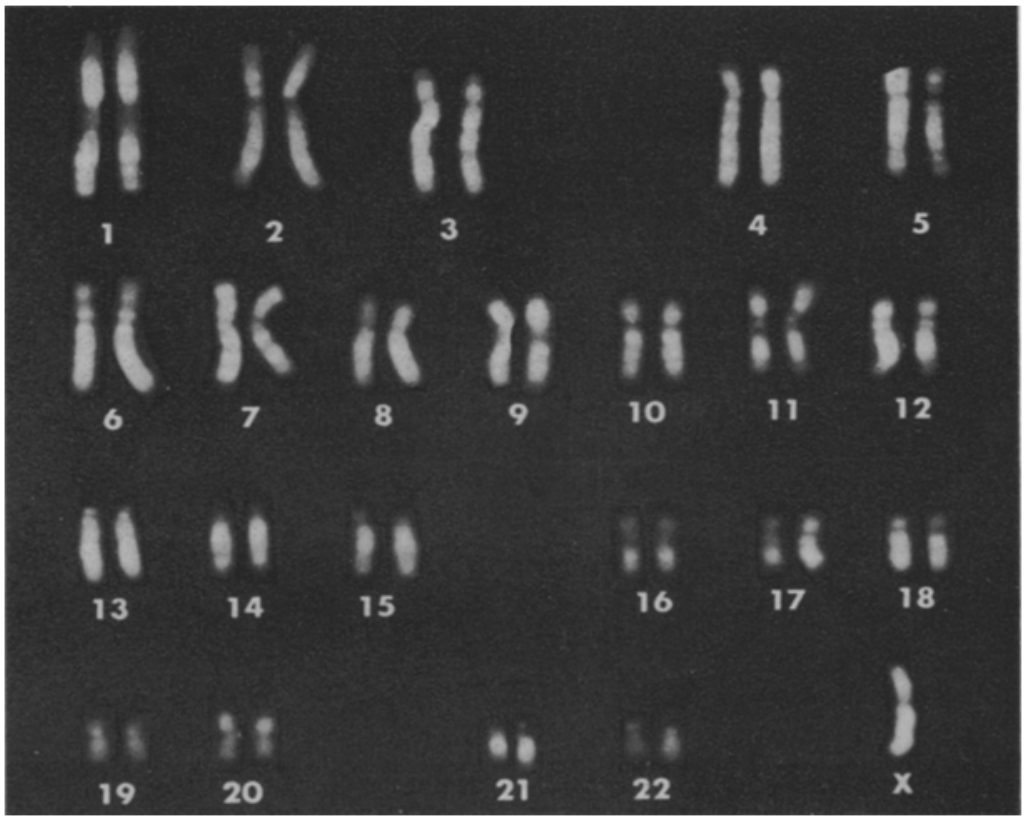

Fig. 3. Q banded karyotype of a 45,X cell from lymphoblastoid cell line established by EBV. 


\section{DISCUSSION}

In the present study, the diagnosis of Duchenne muscular dystrophy of the patient was established by clinical features such as muscular weakness with muscular pseudohypertrophy, particularly at the calves, the progression of muscle atrophy, the positive family history, the serum CPK and aldolase determinations and the muscle biopsy. The patient showed no clinical features of Turner's syndrome, since the majority of cultured lymphocytes and fibroblasts showed a normal karyotype, $46, \mathrm{XX}$.

The patient's mother must be a carrier of the DMD gene because she has the family history and high serum CPK levels. The X chromosome in cells with $45, X$ might be derived from the mother and may have the DMD gene.

Only $7 \%$ of cells were $45, \mathrm{X}$ in cultured fibroblasts. About $20 \%$ of cells, however, were $45, \mathrm{X}$ in lymphoblastoid cell line (LCL). Judging from the manifestation of DMD, the patient should have a considerably large proportion of $45, \mathrm{X}$ cells in her muscle. The paternal $X$ chromosome may be preferentially lost in myoblast by the postzygotic non-disjunction. Consequently the DMD gene derived from the mother is expected to be expressed in all $45, \mathrm{X}$ cells and assuming a random inactivation of the $X$ chromosome, in half the $46, X X$.

The 45,X chromosome constitution in two cases with Turner's syndrome and typical Duchenne muscular dystrophy was reported (Walton, 1957; Chelly et al., 1986). Microdeletion of $X$ chromosome was detected by Southern blot analysis of DNA in Chelly's case (1986). The deletion had occurred de novo on the normal $\mathrm{X}$ chromosome derived from her mother.

A few mosaics similar to our case were reported (Ferrier et al., 1965; Jalbert et al., 1966; Bortolini et al., 1986). In all three cases, the stigmata of Turner's syn-

Table 2. Published abnormal chromosomes in number in girls with Duchenne muscular dystrophy.

\begin{tabular}{lccc}
\hline \multicolumn{1}{c}{ Reference } & Chromosome constitution & $\%$ of $45, \mathrm{X}^{2}$ & $\begin{array}{c}\text { Turner's } \\
\text { syndrome }\end{array}$ \\
\hline Walton (1957) & $45, \mathrm{X}$ & 100 & + \\
Ferrier et al. $(1965)$ & $45, \mathrm{X} / 46, \mathrm{X}, \mathrm{Xp}-$ or $46 \mathrm{X}, \mathrm{r}(\mathrm{X})$ & 38 & + \\
Jalbert et al. $(1966)$ & $45, \mathrm{X} / 46, \mathrm{XX} / 47, \mathrm{XXX}$ & 75 & + \\
Bortolini et al. $(1986)$ & $45, \mathrm{X} / 46, \mathrm{XX} / 47, \mathrm{XXX}$ & 36 & + \\
Chelly et al. $(1986)$ & $45, \mathrm{X}$ & 100 & + \\
Present case & $45, \mathrm{X} / 46, \mathrm{XX}$ & 1 & - \\
\hline
\end{tabular}

$\mathrm{Xp} \rightarrow$ : Short arm of X chromosome was missed. $r(\mathrm{X})$ : Ring X chromosome. a Chromosomal analyses in peripheral blood lymphocytes.

Vol. 32, No. 3, 1987 
drome were seen and the proportions of $45, \mathrm{X}$ cells were much higher than in our case (Table 2). The karyotype of our case obtained using chromosome analyses of PHA-stimulated lymphocytes could not exclude a possibility of a technical artifact during preparation, because only one cell in 77 cells examined was found to be $45, \mathrm{X}$ karyotype. By using EB virus-transformed lymphoblastoid cell line, however, the karyotype of this case was finally identified to be a mosaic $45, \mathrm{X} / 46, \mathrm{XX}$. The incidence of $45, \mathrm{X}$ cells were $20 \%$ for EBV-transformed LCL. On the other hand, in fibroblast cultures from a skin biopsy, the $45, \mathrm{X}$ cells were about $7 \%$. From these results, there might be a wide range of variation in the proportion of $45, \mathrm{X}$ cells in different tissues. Therefore, the proportion of $45, \mathrm{X}$ cells in the present case is presumed to be much higher in myoblasts than in other tissues.

\section{REFERENCES}

Bortolini, E.R., da Silva, D.M., Chequer, R.S., Vianna-Morgante, A.M., and Zatz, M. 1986. Brief clinical report: Duchenne muscular dystrophy in a girl with a $45, \mathrm{X} / 46, \mathrm{XX} / 47, \mathrm{XXX}$ chromosome constitution. Am. J. Med. Genet. 25: 239-243.

Canki, N., Dutrillaux, B., and Tivadar, I. 1979. Dystrophie musculaire de Duchenne chez une petite fille porteuse dúne translocation $\mathrm{t}(\mathrm{X} ; 3)(\mathrm{p} 21 ; \mathrm{q} 13)$ de novo. Ann. Genet. (Paris) 22:35-39.

Chelly, J., Marlhens, F., Marec, B.L., Jeanpierre, M., Lambert, M., Hamard, G., Dutrillaux, B., and Kaplan, J.C. 1986. De novo DNA microdeletion in a girl with Turner syndrome and Duchenne muscular dystrophy. Hum. Genet. 74: 193-196.

Ferrier, P., Bamatter, F., and Klein, D. 1965. Muscular dystrophy (Duchenne) in a girl with Turner's syndrome. J. Med. Genet. 2: 38-46.

Jalbert, P., Mouriquand, C.L., Beaudoing, A., and Jaillard, M. 1966. Myopathie progressive de type Duchenne et mosaique $\mathrm{XO} / \mathrm{XX} / \mathrm{XXX}$ : considérations sur la genèse de la fibre musculaire striee. Ann. Genet. (Pairs) 9: 104-108.

Lindenbaum, R.H., Clarke, G., Patel, C., Moncrieff, C., and Hughes, J.T. 1979. Muscular dystrophy in an X; 1 translocation female suggests that Duchenne locus is on $\mathrm{X}$ chromosome short arm. J. Med. Genet. 16: 389--392.

Nielsen, L.B. and Nielsen, I.M. 1984. Turner's syndrome and Duchenne muscular dystrophy in a girl with an X; autosome translocation. Ann. Genet. (Paris) 27: 173-177.

Saito, F., Tonomura, A., Kimura, S., Misugi, N., and Sugita, H. 1985. High-resolution banding study of an $\mathrm{X} / 4$ translocation in a female with Duchenne muscular dystrophy. Hum. Genet. 71: $370-371$.

Walton, J.N. 1957. The inheritance of muscular dystrophy. Acta Genet. Stat. Med. 7: 318-320. 